\title{
Germination and morphology of fruits, seeds and plants of Cereus jamacaru $\mathrm{DC}^{1}$
}

\author{
Haynna Fernandes Abud ${ }^{2 *}$, Magnum de Sousa Pereira ${ }^{3}$, Nayara Roberto \\ Gonçalves $^{4}$, Diego de Sousa Pereira ${ }^{5}$, Antonio Marcos Esmeraldo Bezerra ${ }^{3}$
}

\begin{abstract}
This work aimed to evaluate the germination and morphology of fruits, seeds and description of plant growth stages of mandacaru. The experimental design was completely randomized in a 2 x 3 factorial arrangement, consisting of combinations of two light conditions and three temperature regimes. A daily count of the number of germinated seeds was performed until the $16^{\text {th }}$ day after sowing in order to determine the percentage, speed and time of germination. External and internal aspects were considered for the morphological description. The germination and the development of plants were evaluated for 150 days and featured eight stages of growth, based on morphological differentiation. The fruit has 154,66 $\pm 40,01 \mathrm{~g}$ mass, $82,26 \pm 5,78 \mathrm{~mm}$ length, $62,63 \pm$ $6,63 \mathrm{~mm}$ diameter and $1439 \pm 189,78$ seeds. The temperature of $25^{\circ} \mathrm{C}$ under a photoperiod of $12 \mathrm{~h}$ provides the highest rate of seed germination and the seeds behave as neutral photoblastic. The germination is epigeal and fanerocotyledonary. The growth is slow and after 150 days of sowing the plant presents epicotyl with a large amount of thorns, where the whole plant is $325.30 \mathrm{~mm}$ in length.
\end{abstract}

Index terms: Cactaceae, mandacaru, morphology, seedling growth.

\section{Germinação e morfologia de frutos, sementes e plantas de Cereus jamacaru DC}

\begin{abstract}
RESUMO - Objetivou-se avaliar a germinação, morfologia de frutos, sementes e descrição de estádios de crescimento de plantas de mandacaru. O delineamento experimental foi o inteiramente casualizado, num arranjo fatorial 2 x 3 , constituídos pelas combinações de duas condições de luminosidade e três regimes de temperatura. Contagens diárias do número de sementes germinadas foram realizadas até o $16^{\circ}$ dia da semeadura para a determinação da porcentagem, índice de velocidade e tempo médio de germinação. Para a descrição morfológica das sementes consideraram-se aspectos externos e internos. O processo germinativo e o desenvolvimento das plantas durante 150 dias foram avaliados sendo caracterizados oito estádios de crescimento, baseados na diferenciação morfológica. O fruto apresenta 154,66 $\pm 40,01 \mathrm{~g}$ de massa, comprimento de 82,26 $\pm 5,78 \mathrm{~mm}$, diâmetro de $62,63 \pm 6,63 \mathrm{~mm}$ e $1439 \pm 189,78$ sementes. A temperatura de $25^{\circ} \mathrm{C}$ sob fotoperíodo de 12 horas proporciona a maior taxa de germinação e as sementes comportam-se como fotoblásticas neutras. A germinação é epígea e fanerocotiledonar. O crescimento é lento e após 150 dias da semeadura a planta encontra-se com epicótilo com presença de grande quantidade de espinhos, onde a planta inteira apresenta $325,30 \mathrm{~mm}$ de comprimento.
\end{abstract}

Termos para indexação: Cactaceae, mandacaru, morfologia, crescimento de plantas.

\section{Introduction}

Cacti comprise about 100 genera, where 40 of them are present in Brazil, represented by approximately 200 species distributed in several Brazilian ecosystems, especially in the Northeastern Caatinga (Souza and Lorenzi, 2008). These are plants that are especially prone to survival in dry environments

${ }^{1}$ Submitted on 10/16/2012. Accepted for publication on 04/08/2013.

${ }^{2}$ Universidade Federal de Viçosa, Departamento de Fitotecnia, 36570-000 -

Viçosa, MG, Brasil.

${ }^{3}$ Universidade Federal do Ceará, 60455-760 - Fortaleza, CE, Brasil.

${ }^{4}$ Departamento de Produção Vegetal, USP/ESALQ, Caixa Postal 9, 13418-900 -

Piracicaba, SP, Brasil.
(Rojas-Aréchiga and Vásquez-Yanes, 2000; Souza and Lorenzi, 2008), although species that inhabit rainforests are not uncommon (Souza and Lorenzi, 2008). Mandacaru is a columnar cactus, of multibranch trunk, fitted with yellowish spines; its flowers are large, white, nocturnal and numerous (Braga, 1976). The fruits are dehiscent, of glabrous surface, reddish-purple color, large, containing numerous black seeds

${ }^{5}$ Universidade Federal de Lavras, Caixa Postal 3037, CEP 37200-000 Lavras, MG, Brasil.

*Corresponding author <hfabud@gmail.com> 
scattered on white pulp (Lorenzi and Matos, 2002), serving as food for birds and wildlife of the region, and contributing to the sustainability and conservation of biodiversity (Cavalcanti and Resende, 2006). The plant develops in shallow soils in drier areas of the semi-arid Northeast (Cavalcanti and Resende, 2006).

The propagation of cacti can be performed either sexually as asexually (Rojas-Aréchiga and Vásquez-Yanes, 2000). The aspects of germination and morphological characterization of fruits, seeds and seedlings, in cacti, particularly of native species in Brazil are scarce in the literature. However, several species of cacti have been characterized regarding their morphological, physiological and ecophysiological aspects, such as in: Stenocereus stellatus (Rojas-Aréchiga et al., 2001); Stenocereus queretaroensis (Barrera and Nobel, 2003); Stenocereus queretaroensis (Loza-Cornejo et al., 2003); Hylocereus setaceus (Simão et al., 2007); Denmoza rhodacantha (Méndez, 2007); Melocactus bahiensis (Lone et al., 2007); Trichocereus terscheckii (Ortega-Baes and Rojas-Aréchiga, 2007); Hylocereus undatus (Andrade et al., 2008); Pilosocereus pachycladus (Abud et al., 2010); Pilosocereus gounellei (Abud et al., 2012); Cereus jamacaru (Alencar et al., 2012a; 2012b), among other works.

Studies on the morphology of germination, in addition to contributing with information on the propagation of the species, address the germination classification relative to the position of the cotyledons, which assists the interpretation and standardization of germination tests (Beltrati, 1995). It is essential to know the morphological characteristics of seeds in order to maintain biodiversity, as well as to understand and describe the germination process (Oliveira et al., 2006). Furthermore, the combination of information about the biometric characteristics of seeds and seedlings provides subsidies for recognition of the species in the field and in seed samples and can also help in the differentiation of species of the same genus (Beltrati, 1995; Cruz et al., 2001).

Given the above information, and considering the lack of information on the germination and growth of native caatinga cacti, this study aimed to evaluate the germinative behavior of seeds and describe the morphology of fruits, seeds and stages of growth and development of Cereus jamacaru plants.

\section{Materials and Methods}

Mature Cereus jamacaru fruits were collected from the Experimental Farm of the Curu Valley, Federal University of Ceará (UFC), located in Pentecoste-CE. After harvest, the fruits were packed in plastic bags and transported to the Laboratory of Seed Analysis (UFC), in Fortaleza-CE.

The length and diameter were determined in ten fruits, where the length is measured at the region between the base and the apex, while the diameter is measured at the intermediate region of the fruit. These measurements were taken with a digital caliper with a resolution of $0.01 \mathrm{~mm}$. These assessments yielded the following descriptive statistics: mean, confidence interval of the mean, standard deviation and coefficient of variation. For the description of the morphology of the fruits, external aspects were considered, such as type, format, epicarp color, fruit weight, seed number and seed mass per fruit.

The extraction of seeds was carried out by opening the fruits and removing the pulp by maceration in a colander and rinsing under running water. Next, the seeds were shade dried for 48 hours. The water content and mass of one thousand seeds were determined, as described in the Rules for Seed Testing (Brasil, 2009).

For seed germination, two light conditions (photoperiod of $12 \mathrm{~h}$ and total darkness) and three temperature regimes (25, 30 and $20-30{ }^{\circ} \mathrm{C}$ ) were tested, arranged in a $2 \times 3$ factorial arrangement in a completely randomized design with four replications of 50 seeds each. Seeds were put on Petri dishes of $14 \mathrm{~cm}$ in diameter, with a substrate consisting of two sheets of filter paper moistened with distilled water at a ratio of 2.5 times the mass of dry paper. The germinated seeds were counted daily until the $16^{\text {th }}$ day of sowing. Seeds were considered germinated once they originated seedlings with primary root with at least $1 \mathrm{~mm}$ in length. Once in possession of daily and final count data for germinated seeds, the following variables were obtained: germination percentage - performed by counting normal seedlings from each experimental unit, with the results expressed in percentage; germination speed index - according to the methodology recommended by Maguire (1962); mean germination time - according to the formula proposed by Labouriau (1983), with the result expressed in days. Seeds kept in the dark were observed under green light. The data were submitted to a variance analysis and the means were compared by Tukey test at $5 \%$ probability.

For the description of the morphology of mandacaru seeds, 50 units were used, taken at random in the work sample. External (type, shape, structure, coloring, position of the hilum and micropyle) and internal (embryo and tissue reserves) aspects were assessed, according to Barroso et al. (1999) and Beltrati (1995). To characterize the internal morphology, seeds were previously soaked in distilled water for $24 \mathrm{~h}$, for softening and moisturizing. After this period, longitudinal slides were performed and then observed under magnifying glass INALH - MLS 250.

The descriptions and illustrations of the external morphology of seedlings and plantlets were performed by sowing 200 seeds in polyethylene trays containing 
vermiculite and humus as substrate in the proportion of 1:1 (v / v), kept under greenhouse conditions (50\% shading, average temperature of $29,6{ }^{\circ} \mathrm{C}$ and relative humidity of $60 \%$ ) and intermittent irrigation. The characterization of the final stages of growth was measured in plants transplanted 70 days after sowing, from the tray into polyethylene bags of $12 \times 15 \mathrm{~cm}$, containing sand and humus as substrate in the volumetric ratio of $1: 1$. The seedling germination and growth process was evaluated over a period of 150 days, with eight stages of growth being characterized, based on morphological differentiation. For the characterization of seedlings, the most vigorous were selected, evidencing: root system, cervix, epicotyl and hypocotyl, according to Barroso et al. (1999). The morphological aspects of seeds, germination and seedlings were illustrated by hand.

\section{Results and Discussion}

The mass of one thousand mandacaru seeds was $4.42 \mathrm{~g}$, that is, one kilogram has 226,224 seeds. The water content of the seed lot used for the work was $10 \%$. One of the factors that affect seed mass is the water content, which may vary according to the conditions of the sampling, with age and degree of maturity of seeds (Marcos-Filho, 2005).

Mandacaru seeds subjected to a constant temperature of $25{ }^{\circ} \mathrm{C}$ and photoperiod of $12 \mathrm{~h}$ showed the highest germination percentage $(89 \%)$ and the highest germination speed index value (6.7), which did not differ from that obtained at $30{ }^{\circ} \mathrm{C}$ (Table 1), which is consistent with the results found by Alencar et al. (2012a). A similar germination behavior was observed for Pilosocereus pachycladus seeds, where constant 25 and $30^{\circ} \mathrm{C}$ temperatures provided the best results in terms of percentage and germination speed (Abud et al., 2010). Melocactus bahiensis seeds showed similar germination behavior where the temperature of $25^{\circ} \mathrm{C}$ also resulted in higher percentages and germination speed index (Lone et al., 2007). Rojas-Aréchiga and Vásquez-Yanes (2000) state that favorable temperatures for germination of cacti are between 15 and $35^{\circ} \mathrm{C}$ and the optimum temperature for germination is around $25^{\circ} \mathrm{C}$.

Table 1. Means of percentage, speed index (GSI) and mean germination time (MGT) of mandacaru seeds under three temperatures and two light conditions.

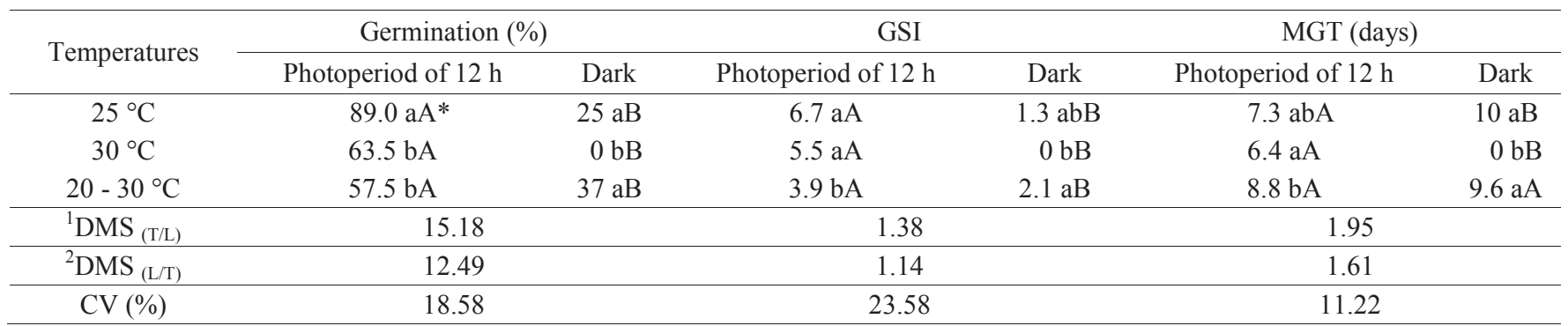

*Means followed by the same letter, lowercase in the columns and uppercase in the lines, do not differ by Tukey's test $(\mathrm{p}<0,05)$.

${ }^{1}$ Minimum significant difference regarding the temperature unfolding inside the photoperiod.

${ }^{2}$ Minimum significant difference referring to the photoperiod unfolding inside the temperature.

In the absence of light, occurred the inhibition of germination at $30{ }^{\circ} \mathrm{C}$, while at 25 and $20-30{ }^{\circ} \mathrm{C}$ was observed only a reduction in the percentage of germination, suggesting that the minimum phytochrome concentration in active form present in the seeds was enough to trigger the germination process at these temperatures, through the synthesis of hormones and the onset of transcription of the genetic message (Marcos-Filho, 2005). In the dark (Table 1) no statistical difference was found between the mean values obtained at $25{ }^{\circ} \mathrm{C}(25 \%)$ and $20-30{ }^{\circ} \mathrm{C}(37 \%)$. However, given the absence or low percentage of seeds germinated in this condition, it is recommended that the germination of mandacaru be held in light conditions. In a similar study conducted with seeds of Cereus jamacaru, Meiado et al. (2010) state that in any of the tested temperatures seed germination was verified in full dark, classifying the species as positive photoblastic. Other studies with cacti claim that germination is stimulated by light and thus, the seeds are classified as positive photoblastic (Rojas-Aréchiga and Vásquez-Yanes, 2000; Ortega-Baes and Rojas-Aréchiga, 2007). There are no reports of negative photoblastism in cacti seeds.

The temperature of $30{ }^{\circ} \mathrm{C}$ and photoperiod of $12 \mathrm{~h}$ provided the lowest mean germination time of mandacaru seeds (6.4 days). Under dark conditions, the full mean germination time was 10 days for the temperature of $25^{\circ} \mathrm{C}$ and 9.6 days to $20-30{ }^{\circ} \mathrm{C}$.

The mandacaru fruits showed red coloring epicarp after reaching physiological maturity (Figure 1A). These are fleshy capsules, with irregular dehiscence, piriformis, polispermic, presenting a thick and juicy pericarp (Figures 1A, 1B and 1C). 


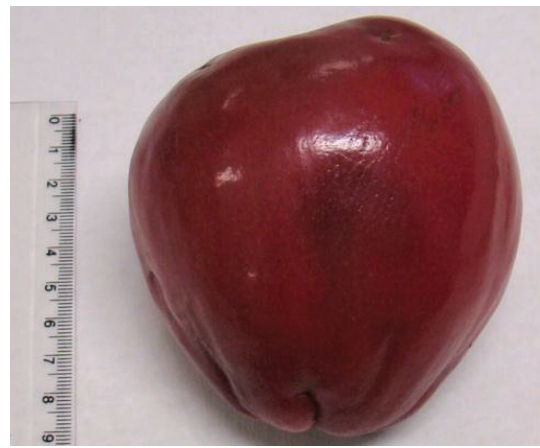

A

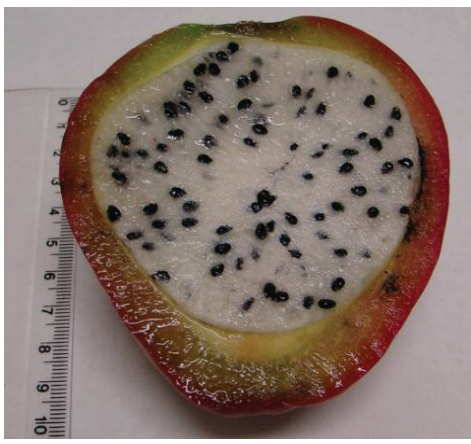

B

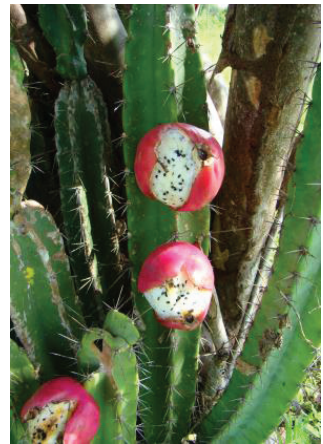

$\mathrm{C}$

Figure 1. External (A) and internal (B) aspects of the ripe fruit and the plant with mandacaru fruit (C).

The mandacaru fruit showed $82.36 \pm 5.78 \mathrm{~mm}$ length and $62.63 \pm 6.63 \mathrm{~mm}$ in diameter, $154.66 \pm 40.01 \mathrm{~g}$ in mass and contained $1439 \pm 189.78$ black seeds (Table 2) dispersed in the white pulp (Figure 1B). It was found that the fruit and seeds' masses and the number of seeds per fruit had higher relative dispersions, as their coefficients of variation denote. In their review, Rojas-Aréchiga and Vázquez-Yanes (2000) reported no difference in the number of seeds per fruit even within species, depending on age, plant size, and other factors.

Table 2. Biometric characterization of mandacaru fruits and seeds.

\begin{tabular}{lccc}
\hline \multicolumn{1}{c}{ Characteristics } & Mean $^{1}$ & Standard-deviation & CV (\%) \\
\hline Fruit mass $(\mathrm{g})$ & $154.66 \pm 40.01$ & 64.56 & 41.74 \\
Fruit length $(\mathrm{mm})$ & $82.36 \pm 5.78$ & 9.32 & 11.32 \\
Fruit diameter $(\mathrm{mm})$ & $62.63 \pm 6.63$ & 10.70 & 17.08 \\
$\mathrm{~N}^{\circ}$ of seeds/fruit & $1439 \pm 189.78$ & 306.19 & 21.28 \\
Seed mass $(\mathrm{g})$ & $5.93 \pm 1.52$ & 2.46 & 41.48 \\
\hline
\end{tabular}

${ }^{1}$ Confidence interval (95\%) calculated by the expression: $\bar{x} \pm t_{\alpha / 2} \frac{s}{\sqrt{n}}$

Cacti seeds have various shapes, colors, sizes and appearances. Formats can present reniform, globular, ovoid, pyriform and colorations black, brown, reddish brown, among others (Rojas-Vasquez-Yanes and Aréchiga, 2000). Mandacaru seeds are stenospermics, unalbuminous, the testa is wrinkled and black in color, matte, slightly obovate-oblique format (Figures 2A and 2B). Seeds are campylotropous, exotestal and bitegumented. The embryo is easily seen when seeds are hydrated, is peripheral, has a white color and occupies almost the whole space of the seed, and it is cylindrical and large. It displays reserves in the cotyledons, of white color and firm consistency (Figure 2C).

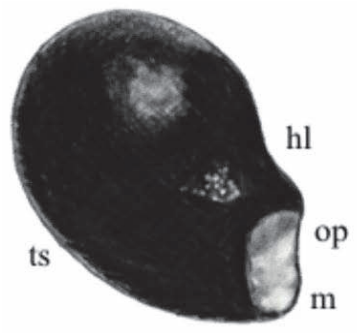

A

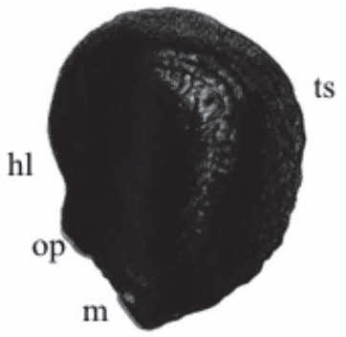

B

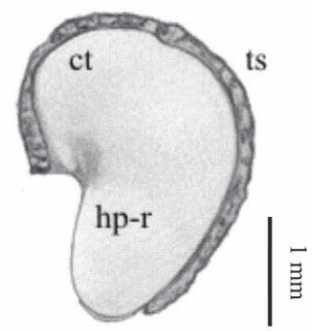

C

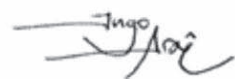

Figure 2. External (A, B) and internal aspects (C) of mandacaru seeds. Legend: ct - cotyledons; hl - hilo, hp-r - hypocotyl-radicle axis; $\mathrm{m}$ - micropyle; op - operculum; ts - testa. 
Eight stages of growth of mandacaru were recorded from morphological changes presented to 150 days after sowing (Figure 3). The mandacaru seed presented a length of 3.0 $\mathrm{mm}$ (Figure 3A). Three days after seeding, radicle protrusion occurred by opening the operculum (Figure 3B). In a similar study with facheiro seeds (Pilosocereus pachycladus) a cactus found in the Northeastern Caatinga, which presents morphological characteristics of plants, fruits and seeds similar to mandacaru, Abud et al. (2010) observed that seeds present a medium length of $1.55 \mathrm{~mm}$ and that the root protrusion occurs approximately $96 \mathrm{~h}$ after sowing. The presence of a higher amount of reserve material in the mandacaru seed may have contributed to root protrusion occurring earlier than in facheiro seeds, through activation of enzymes by absorption and mobilization of these substances, and its translocation to growth points.

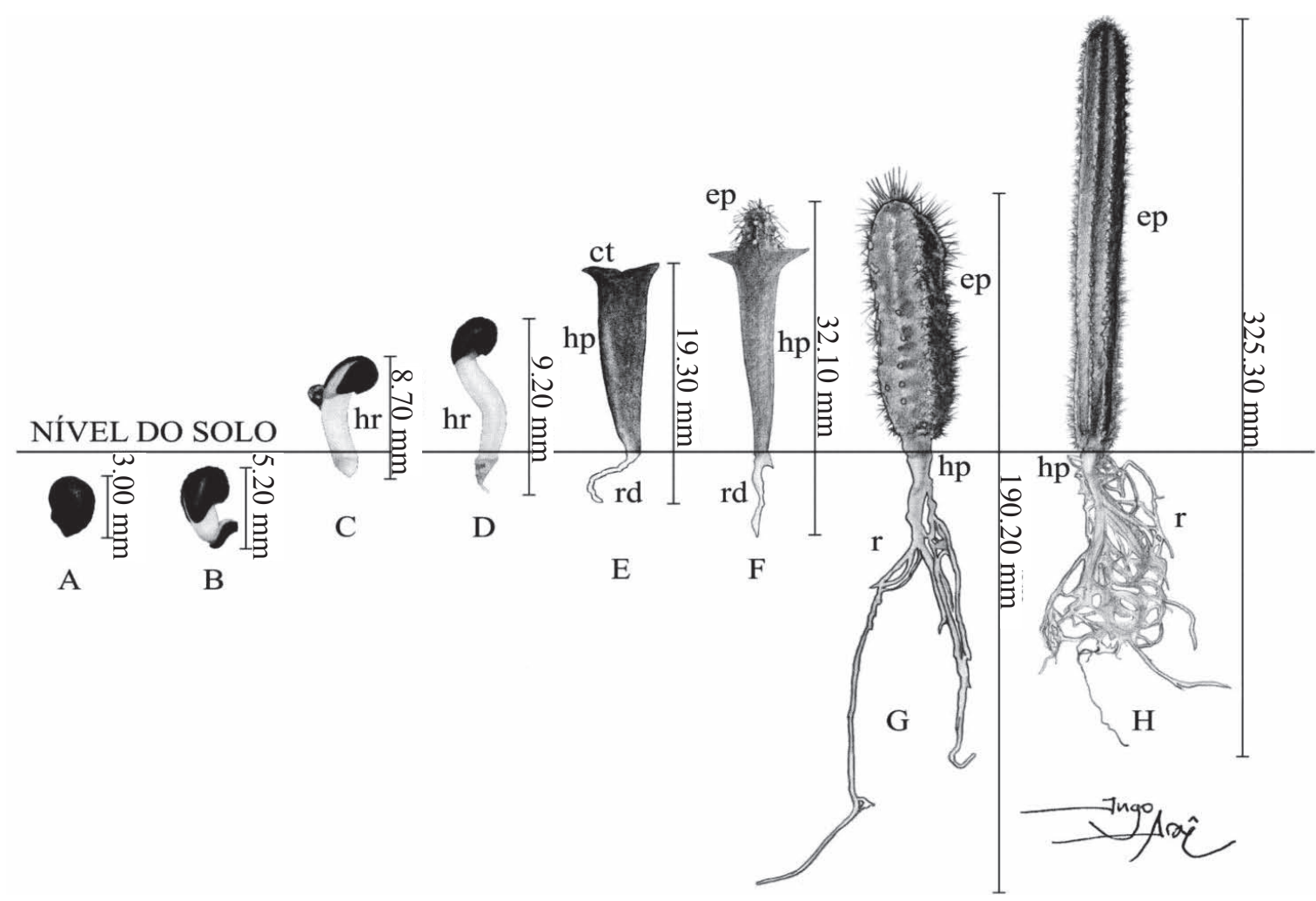

Figure 3. Morphological aspects of the seed and different stages of growth of mandacaru until 150 days after sowing. Legend: hr - hypocotyl-radicle axis; hp - hypocotyl; rd - radicle; ct-cotyledons; ep - epicotyl; r - root.

Then, there was the development of the hypocotyl, which grew rapidly, and five days after sowing the seedlings reached $8.7 \mathrm{~mm}$ in size, from the root to the shoot apex (Figure 3C). At eight days after sowing, the seedling measured $9.2 \mathrm{~mm}$ in total length (Figure 3D). At 17 days it was observed that the hypocotyl was completely erect, and the cotyledons were exposed, featuring the seedling as phanerocotylar. At this stage of development, the plant had a total length of 19.30 $\mathrm{mm}$ from the cotyledons to the primary root (Figure 3E). Also in Figure (3E), it is possible to visualize the pattern adopted in this research for the count of normal seedlings during the germination test.

The growth of the epicotyl proved to be slow, starting at 60 days after sowing, where the appearance of bristles between the cotyledons was verified, with a total length of $32.10 \mathrm{~mm}$ (Figure
3F). At 90 days after sowing, the plant presented many thorns and expansion of the epicotyl, and was approximately 190.20 $\mathrm{mm}$ in size (Figure 3G). Germination of mandacaru is epigean and phanerocotylar. A similar study was done by Salles (1987) with Cephalocereus fluminensis, where the development stages of the seedling were observed from germination through early development of the epicotyl, which occurred at 90 days after sowing. In Pilosocereus pachycladus at 150 days after sowing, the plant's epicotyl was growing with the presence of large amounts of thorns, and was $94.31 \mathrm{~mm}$ in length, from the root to the shoot apex (Abud et al., 2010). From 90 days after sowing, morphological changes observed were small, occurring only upon increase in the size of the plants, until 150 days after sowing, when the total length of the plant from the root to the shoot apex was $325.30 \mathrm{~mm}$ (Figure 3H). 


\section{Conclusions}

The temperature of $25^{\circ} \mathrm{C}$ under a photoperiod of $12 \mathrm{~h}$ gives the highest rate of germination of Cereus jamacaru (mandacaru) seeds and they behave as neutral photoblastic.

Germination of mandacaru seeds is epigean and phanerocotylar.

The growth of the mandacaru plant is slow, and at 150 days after sowing, the plant presented an epicotyl with many thorns; the plant's total length is approximately $325.30 \mathrm{~mm}$.

\section{References}

ABUD, H.F.; GONÇALVES, N.R.; REIS, R.G.E.; PEREIRA, D.S.; BEZERRA, A.M.E. Germinação e expressão morfológica de frutos, sementes e plântulas de Pilosocereus pachycladus Ritter. Revista Ciência Agronômica, v.41, n.3, p.468-474, 2010. http://www.scielo.br/scielo.php?pid=s1806$66902010000300021 \&$ script $=$ sci arttext

ABUD, H.F.; GONÇALVES, N.R.; PEREIRA, M.S.; PEREIRA, D.S.; REIS, R.G.E.; BEZERRA, A.M.E. Germination and morfological characterization of the fruits, seeds and seedlings of Pilosocereus gounellei. Brazilian Journal of Botany, v.35, n.1, p.11-16, 2012. http://www.scielo.br/scielo. php?pid=S1806-99592012000100003\&script=sci_arttext

ALENCAR, N.L.M.; GOMES-FILHO, E.; INNECCO, I. Cereus jamacaru seed germination and initial seedling establishment as a function of light and temperature conditions. Scientia Agricola, v.69, n.1, p.70-74, 2012a. http://www. scielo.br/scielo.php?pid=S0103-90162012000100010\&script=sci_arttext

ALENCAR, N.L.M.; INNECCO, R.; GOMES-FILHO, E.; GALLÃO, M.I.; ALVAREZ-PIZARRO, J.C.; PRISCO, J.T.; OLIVEIRA, A.B. Seed reserve composition and mobilization during germination and early seedling establishment of Cereus jamacaru D.C. ssp. jamacaru (Cactaceae). Anais da Academia Brasileira de Ciências, v.84, n.3, p.823-832, 2012b. http://www. scielo.br/scielo.php?pid=s0001-37652012000300024\&script=sci_arttext

ANDRADE, R.A.; OLIVEIRA, I.V.M.; SILVA, M.T.H.; MARTINS, A.B.G. Germinação de Pitaya em diferentes substratos. Revista Caatinga, v.21, n.1, p.71-75, 2008. http://periodicos.ufersa.edu.br/revistas/index.php/sistema/article/ view/610/258

BARRERA, E.D.; NOBEL, P.S. Physiological ecology of seed germination for the columnar cactus Stenocereus queretaroensis. Journal of Arid Enviroments, v.53, p.297-306, 2003. http://www.oikos.unam.mx/CIEco/lafea/images/stories/ lafea/papers/007.pdf

BARROSO, G.M.; MORIM, M.P.; PEIXOTO, A.L.; ICHASO, C.L.F. Frutos e sementes: morfologia aplicada à sistemática de dicotiledôneas. Viçosa: UFV, 1999. 443p.

BRAGA, R. Plantas do Nordeste, especialmente do Ceará. 3.ed. Mossoró: Escola Superior de Agricultura de Mossoró, 1976. 540p.

BRASIL. Ministério da Agricultura, Pecuária e Abastecimento. Regras para análise de sementes. Ministério da Agricultura, Pecuária e Abastecimento. Secretaria de Defesa Agropecuária. Brasília: MAPA/ACS, 2009. 395p. http:// www.bs.cca.ufsc.br/publicacoes/regras\%20analise\%20sementes.pdf

CAVALCANTI, N.B.; RESENDE, G.M. Consumo de mandacaru (Cereus jamacaru P. DC.) por caprinos na época seca do semi-árido de Pernambuco. Revista Caatinga, v.19, n.4, p.402-408, 2006. http://periodicos.ufersa.edu.br/ revistas/index.php/sistema/article/view/99/71

CRUZ, E.D.; MARTINS, F.O.; CARVALHO, J.E.U. Biometria de frutos e sementes e germinação de jatobá-curuba (Hymenea intermedia Ducke,
Leguminosae, Caesalpinoideae). Revista Brasileira de Botânica, v.24, n.2, p.161-165, 2001. http://www.scielo.br/pdf/rbb/v24n2/a05v24n2.pdf

LABOURIAU, L.G. A germinação das sementes. Washington, D.C.: Secretaria Geral da OEA, 1983. 174p.

LONE, A.B.; TAKAHASHI, L.S.A.; FARIA, R.T.; UNEMOTO, L.K. Germinação de Melocactus bahiensis (CACTACEAE) em diferentes substratos e temperaturas. Scientia Agrária, v.8, n.4, p.365-369, 2007. http:// dialnet.unirioja.es $/$ servlet/articulo? codigo $=2908601$

LORENZI, H.; MATOS, F.J.A.M. Plantas medicinais no Brasil: nativas e exóticas cultivadas. Nova Odessa, SP, 2002. 512p.

LOZA-CORNEJO, S.; TERRAZAS, T.; LOPEZ-MATA, L.; TREJO, C. Características morfo-anatómicas y metabolismo fotosintético en plántulas de Stenocereus queretaroensis (Cactaceae): su significado adaptativo. Interciência, v.28, n.2, p.83-89, 2003. http://redalyc.uaemex.mx/src/inicio/ ArtPdfRed.jsp?iCve=33907704

MARCOS-FILHO, J. Fisiologia de sementes de plantas cultivadas. Piracicaba: FEALQ, 2005. 495p.

MAGUIRE, J.D. Speed of germination-aid in selection and evaluation for seedling emergence and vigor. Crop Science, v.2, p.176-177, 1962.

MEIADO, M.V.; ALBUQUERQUE, L.S.C.; ROCHA, E.A. ROJASARÉCHIGA, M.; LEAL, I.R. Seed germination responses of Cereus jamacaru DC. ssp. jamacaru (Cactaceae) to environmental factors. Plant Species Biology, v.25, p.120-128, 2010.

MÉNDEZ, E. Germination of Demonza rhodacantha (Salm-Dyck) Britton \& Rose (Cactaceae). Journal of Arid Environments, v.68, p.678-682, 2007.

OLIVEIRA, A.K.M.; SCHLEDER, E.D.; FAVERO, S. Caracterização morfológica, viabilidade e vigor de sementes de Tabebuia aurea (Silva manso) Benth. \& Hook. F. ex. S. Moore. Revista Árvore, v.30, n.1, p.25-32, 2006. http:// www.scielo.br/scielo.php?pid=S0100-67622006000100004\&script=sci_arttext

ORTEGA-BAES, P.; ROJAS-ARÉCHIGA, M. Seed germination of Tricocereus terscheckii (Cactaceae): Light, temperature and giberellinic acid effects. Journal of Arid Environments, v.69, p.169-176, 2007. http:// www.scielo.br/scielo.php?script=sci_nlinks\&ref=000094\&pid=S18066690201000030002100019\&lng=es

ROJAS-ARÉCHIGA, M.; CASAS, A.; VÁZQUEZ-YANES, C. Seed germination of wild and cultivated Stenocereus stellatus (Cactaceae) from the TehuacánCuicatlán Valley, Central México. Journal of Arid Environments, v.49, p.279-287, 2001. http://www.sciencedirect.com/science/article/pii/S014019630190789X

ROJAS-ARÉCHIGA, M.; VÁSQUEZ-YANES, C. Cactus seed germination: a review. Journal of Arid Environments, v.44, p.85-104, 2000. http:// opuntiads.com/O/zpdf/cactus\%2520review.pdf

SALLES, H.G. Expressão morfológica de sementes e plântulas I. Cephalocereus fluminensis (Miq) Britton e Rose (Cactaceae). Revista Brasileira de Sementes, v.9, n.1, p.73-81, 1987. http://www.abrates.org.br/ revista/artigos/1987/v9n1/artigo05.pdf

SIMÃO, E.; SOCOLOWSKI, F.; TAKAKI, M. The epiphytic Cactaceae Hylocereus setaceus (Salm-Dick ex DC.) ralf bauer seed germination is controlled by light and temperature. Brazilian Archives of Biology and Technology, v.50, n.4, p.655-662, 2007. http://www.scielo.br/scielo. php?pid=s1516-89132007000400011\&script $=$ sci_arttext

SOUZA, V.C., LORENZI, H. Botânica sistemática: guia ilustrado para identificação das famílias de Angiospermas da flora brasileira. Nova Odessa, SP: Instituto Plantarum, 2008. 704p. 